\title{
ПРАВОВЫЕ ОСОБЕННОСТИ ПРЕБЫВАНИЯ ПОЛЯКОВ - УЧАСТНИКОВ ЯНВАРСКОГО ВОССТАНИЯ — В ИРКУТСКОЙ ССЫЛКЕ В 1863-1883 гг.
}

\begin{abstract}
АНнотАция. Статья посвящена анализу правовых условий пребывания поляков участников Январского национально-освободительного восстания - в Иркутской ссылке в период 1863-1883 гг. Поступление на территорию губернии значительного контингента ссыльных поляков вызвало перестройку органов управления каторгой (создание «особого комендантства» в Нерчинском горном округе), принятие отдельных правил и положений, усиливающих и ужесточающих надзор за польскими поселенцами, жестко регламентирующих возможности их перемещения внутри губернии, трудоустройства и выбора рода занятий. Вместе с тем, хронический дефицит в Сибири квалифицированных рабочих и служащих заставлял местную администрацию разрешать использование труда поляков в самых различных отраслях управления, предпринимательства, торговли и производства. К тому же государство стремилось и в ссылке сохранить для поляков сословные привилегии. Анализ документов позволяет утверждать, что для шляхтичей и помещиков условия невольного пребывания в Сибири были сравнительно легче, чем для соотечественников из мещанского или крестьянского сословия.
\end{abstract}

кЛючЕВыЕ слОВА. Январское восстание 1863 г.; ссыльные поляки; всемилостивейшие манифесты; Нерчинская каторга; ссылка на поселение; водворение; житье.

ИНФОРМАЦИЯ О СТАТЬЕ. Дата поступления 17 августа 2016 г.; дата принятия к печати 5 сентября 2016 г.; дата онлайн-размещения 30 сентября 2016 г.

\author{
A. A. Ivanov \\ Irkutsk State University, \\ Irkutsk, Russian Federation
}

\section{LEGAL FEATURES OF POLES' SOJOURN - PARTICIPANTS OF JANUARY REVOLT - IN IRKUTSK EXILE IN 1863-1883}

\begin{abstract}
The article is devoted to analysis of legal issues of Poles' sojourn - participants of January national liberation revolt - in Irkutsk exile over the period of 1863-1883. The arrival on the Province territory of a considerable group of the Polish exiles caused reorganization of governing bodies of the hard labor administration (creation of "a special commandant's office» in the Nerchinsk Miming District), adoption of special rules and provisions which strengthened and toughened supervision over the Polish settlers, that strictly regulated possibilities of their movement within the Province, employment and selection of an occupation. At the same time, chronic deficit in Siberia of skilled workers and employees forced the local administration to allow the use of Poles' work in a wide variety of management, entrepreneurship, trade and production. Besides, the government strived to preserve the class privileges for the Poles even in the exile. The analysis of documents allows to claim that for the noblemen and landlords the conditions of the Siberian sojourn in Siberia were comparably easier than those for their compatriots from petty-bourgeois or peasantry classes.

KEYWORDS. January revolt of 1863; exiled Poles; the most gracious manifestos; Nerchinsk hard labors; exile for settlement; placement; living.

ARTICLE INFO. Received August 17, 2016; accepted September 5, 2016; available online September 30, 2016.
\end{abstract}

(C) А. А. Иванов, 2016

\section{Baikal Research Journal}


История ссылки поляков - участников Январского восстания 1863 г. - в Сибирь и в том числе Иркутскую губернию всегда имела своего постоянного исследователя. Первую страницу этой темы открыли еще современники и участники тех событий Э. Андреоли, А. Гиллер, Дж. Кеннан, С. В. Максимов, З. Либрович, Л. Ф. Пантелеев. В советское время В. А. Дьяковым, Б. Г. Кубаловым, Ф.А. Кудрявцевым, затем В. В. Гапоненко, С. Ф. Ковалем, Н. П. Митиной и далее С. А. Мулиной, Е. В. Семеновым, Б. С. Шостаковичем и некоторыми другими были рассмотрены многочисленные сюжеты данной проблематики, сделаны обобщающие научные выводы, [1, с. 451]. Между тем, правовые условия пребывания польских ссыльных в Сибири и в том числе Прибайкалье изучены еще слабо, что делает данную статью своевременной и актуальной [2, с. 273].

Поляки - участники Январского восстания, ссылаемые в Сибирь, подразделялись в основном на четыре категории: «главари» и инициаторы восстания, а также «эмиссары» и «народные жандармы». Они судились военным судом и отправлялись на каторгу или в ссылку на поселение; рядовые исполнители из шляхетского звания ссылались на житье с определением безотлучного места пребывания или без такового, а сочувствовавшие повстанцам, принадлежавшие к крестьянскому или рабочему сословию, ссылались на водворение [3, с. 88]. Последних было большинство, причем, только по подозрению в лояльности к «бунтовщикам», царскими властями высылались целые села и деревни. Водворяемые попадали в Сибирь «на вечно» и не имели права вернуться на родину.

По всей видимости, первые ссыльные участники Январского восстания стали прибывать в пределы Иркутской губернии уже в конце 1863 - начале 1864 г. По сведениям С. Стшижевской, только из Царства Польского с 29 апреля 1863 г. по 2 января 1864 г. в Сибирь уже было отправлено 497 чел. [4, с. 128]. В марте 1864 г. председательствующий в Совете Главного управления Восточной Сибири К. Н. Шелашников распорядился всех прибывающих в Иркутск политических ссыльных отправлять в Усольский солеваренный завод «до особых распоряжений». В Иркутске для временного постоя поляков были отведены пересыльная тюрьма в Ремесленной слободе, солдатские казармы на Амурской улице и здание Казенной палаты на Луговой. В октябре 1865 г. решением Главного управления Восточной Сибири для прибывающих в Иркутск партий ссыльных из Польши было дополнительно отведено помещение бывшей суконной фабрики [5, с. 66-67].

Можно с уверенностью говорить, что немалая часть сибиряков, в том числе «простых» иркутян, вспоминая добрым словом ссыльных поляков 1831 г., сочувственно отнеслась и к участникам Январского восстания [6, с. 561]. Однако были и такие, кто видел в восставших опасных "бунтовщиков», серьезно угрожавших отечеству. Так, в августе 1864 г. от Иркутского городского общества в Петербург на имя государя было отправлено «всеподданнейшее» письмо, в котором имелись и такие строки: «И до нас, граждан отдаленного Иркутска, дошли вести о замыслах врагов наших, грозящих и планам Твоим, Государь, и благоденствию твоего народа, и целости любезного нашего отечества. Но даль, отделяющая нас от Тебя - источника счастья и блага России, не ослабляет нашей преданности к Тебе и любви к общей нашей отчизне... Когда же наступит время принести на алтарь отечества нужные для спасения достоинства и чести ее жертвы, мы, граждане города Иркутска, что и на деле докажем, что древний русский дух и в недрах отдаленной Сибири сохранился... с не меньшей силою, как и в прочих частях России" [7].

Массовое поступление поляков потребовало быстрой перестройки имевшихся структур управления «ссылочным делом». Уже в ноябре 1863 г. М. С. Корсаков подал в вышестоящие инстанции подробную записку с анализом складывавшейся ситуации, завершив ее предложением сосредоточить всех ссыльных поляков-катор-

\section{Baikal Research Journal}

электронный научный журнал Байкальского государственного университета 
жан в Нерченском горном округе, а для эффективного управления создать «особое Комендантство» наподобие существовавшего во времена декабристов. Корсаков был услышан, комендантское управление, правда, со значительно меньшими полномочиями, чем ранее, организовано и действовало вплоть до апреля 1874 г. [8, с. 109].

В мае 1865 г. М. С. Корсаков обратился в Министерство внутренних дел с другой запиской, в которой подчеркивал, что ныне «число сосланных на поселение в Восточную Сибирь политических преступников за прикосновенность к бывшему польскому мятежу возросло до значительной цифры». Между тем надзор за этими ссыльными был возложен на местных начальников губерний и чинов городской и земской полиции, которые, «по многосложности занятий, ограничиваясь в отношении надзора исполнением лишь формальностей, лишены всякой возможности внимательно наблюдать за действиями этих преступников и своевременно преследовать их злоумышленные намерения». Генерал-губернатор просил назначить в его распоряжение офицера в чине полковника, а «может быть и генерал-майора»; определить делопроизводителя; установить временно должности чиновников по устройству быта политических ссыльных; предоставить в распоряжение генерал-губернатора 10000 р. на секретные расходы; отнести все издержки «в количестве 20480 р. на суммы Царства Польского и процентный сбор в Западных губерниях» ${ }^{1}$.

Министр внутренних дел со своей стороны нашел, что, действительно, ситуация в Восточной Сибири, «в которую назначены по суду более важные преступники», многие из которых по уровню образования имеют «все средства действовать вредно на умы» сибиряков, сложная и требует усиления полицейского надзора, а потому было бы «едва ли удобным отказывать генерал-лейтенанту Корсакову в просимых им средствах». Затем, заручившись предварительным положительным отзывом главного начальника III Отделения, министр внутренних дел осмелился «испросить на сие соизволения» государя и получил резолюцию: «Высочайше повелено исполнить» ${ }^{2}$.

На основании принятого законодательного акта, по всей видимости, уже в 1865-1866 гг. в Иркутске в ранге офицера, «состоящего при генерал-губернаторе для особых поручений», была учреждена должность «для надзора за политическими преступниками» (в чине подполковника или полковника) и три - при главном управлении «для устройства быта политических ссыльных" (подполковник, майор и ротмистр) ${ }^{3}$. Эти офицеры осуществляли как надзор, так и контроль за размещением на территории губернии исключительно ссыльных поляков, прибывших по «Январскому мятежу», и, судя по памятным книжкам, данные должности существовали и в 1870 , и 1873 гг.

В Государственном архиве Иркутской области сохранился отчет одного из таких офицеров «для особых поручений» - подполковника Де Витте, командированного в феврале 1866 г. на Николаевский завод с целью «соображения на месте возможности к помещению в заводе возможно большего числа политических преступников, осужденных в каторжную работу взамен обыкновенных ссыльнокаторжных» .

Де Витте докладывал, что для организации производства с наличною командою и вольнонаемными служащими, владетель завода господин Трапезников предполагает дать работу только 100 ссыльным полякам. «Но как в настоящее время при

${ }^{1}$ Высочайше утвержденный всеподданнейший доклад министра внутренних дел «О временном штате для надзора за политическими преступниками в Восточной Сибири» // Полное собрание законов Российской Империи. Собр. второе. T. XLIII. Отд. второе. 1868. Доп. к XL тому второго собрания законов Российской империи № 42062а. СПб. : Тип. ІІ Отделения Собственной Его Императорского Величества Канцелярии, 1873. 765 с.

${ }^{2}$ Там же. № 42062.

${ }^{3}$ Памятная книжка Иркутской губернии на 1870 г. Адрес-календарь. Иркутск : Изд. Иркут. губерн. стат. комитета, 1870. С. 6-7.

\section{Baikal Research Journal}

электронный научный журнал Байкальского государственного университета 
заводе готовых помещений не имеется, а из числа существующих зданий требуются значительные исправления, то одновременная присылка всего числа неудобна» ${ }^{4}$.

Де Витте докладывал, что Трапезников, соглашаясь разметить у себя поляков, выговорил и ряд условий. Владелец завода принимал ссыльных:

«a $\backslash$ с правом отказаться от них и ранее 5 или 10 лет;

б\с тем, чтобы плату и содержание получать им на равных с тем, что получают ныне;

в \наблюдение за ссыльными вверить особой воинской команде;

$\Gamma \backslash$ провоз на завод, а равно наблюдение за ними должно быть отнесено за счет правительства» ${ }^{5}$.

Применительно к большому количеству участников Январского восстания перестраивалась и деятельность Иркутской губернской экспедиции о ссыльных. В ее штате появились дополнительные писари и даже чиновник, которому «за перевод польской корреспонденции, а также цензорование писем государственных преступников» полагалось достаточно солидное жалованье в размере 700 р. в год

Экспедиции удалось относительно хорошо наладить и отчетность о поляках. Так, теперь от всякого окружного пристава непременно «к 10 числу по истечении каждого месяца» требовались "верные сведения о числе политических ссыльных», находящихся в уезде или волости. Каждое донесение обязательно заканчивалось оценкой обстановки: «проживающие по волости политические ссыльные поведения и образа жизни хорошего в политической неблагонадежности и в других политических проступках замечены не были» ${ }^{7}$

Масштабы ссылки поляков неуклонно возрастали. Тогда 8 января 1866 г. правительство приняло специальные «Правила по устройству быта политических ссыльных, сосланных в Восточную Сибирь из Царства Польского и Западных губерний» . Правила предусматривали для поляков целый ряд серьезных ограничений в трудовой сфере и предпринимательстве. На месте поселения ссыльным запрещалось заниматься воспитанием детей и преподаванием им наук, «искусств и мастерства»; иметь аптеки, фотографии, литографии; иметь занятия во всех правительственных учреждениях; заниматься торговлей вином, медицинской практикой, извозом. Уход на золотые прииски ограничивался для них обязательным «поручительством лиц, нанимающих их" и "разрешением исправника» [9, с. 64-65].

Запрещения - серьезные, но не жестокие. Подобные, может быть, менее тяжелые, действовали и для русских революционеров. Более того, учитывая хронический дефицит мастеровых и ремесленников в Прибайкалье, правительство пыталось использовать здесь ссыльных повстанцев и в качестве источника квалифицированной рабочей силы. Так, согласно «Правилам...» от 8 января 1866 г. «политические преступники в видах обеспечения экономического их быта распределялись по утверждению начальника губернии, применяясь к роду занятий каждого» . Желающие заняться в местах водворения земледелием получали землю в надел, а владеющие рабочими специальностями могли водворяться «в казенные и все имеющиеся в губерниях частные заводы». Кроме этого «политическим преступникам, устроившим свое хозяйство», «могло быть дозволено при хорошем их поведении оставаться на местах водворения" ${ }^{8}$.

Ощутимый дефицит рабочих профессий заставлял власти всячески поощрять обустройство поляков в регионе и на постоянное жительство. Вот, например, состав-

\footnotetext{
${ }^{4}$ Государственный архив Иркутской области (ГАИО). Ф. 24. Оп. Оц. Д. 58. Л. 7.

${ }_{5}^{5}$ Там же. Л. 12.

${ }^{6}$ Там же. Ф. 32. Оп. 1. Д. 379. Л. 5 об.

${ }^{7}$ Там же. Ф. 90. Оп. 4. Д. 475. Л. 10, 11.

${ }^{8}$ Там же. Ф. 24. Оп. Оц. Д. 814. Л. 1.
}

\section{Baikal Research Journal}


ленный в апреле 1873 г. список участников Январского восстания, изъявивших желание остаться после окончания срока ссылки. В списке 54 фамилии, большинство «испрашивали разрешение» поселиться близ промышленных центров в Забайкалье: Артецкий Константин, мыловар - Верхнеудинск, Брудницкий Иван, колбасник - Верхнеудинск, Дрейзонтен Ян, пильщик - Петровский Завод, Зоховский Игнатий, мыловар - Верхнеудинск, Ковальский Николай, портной - Петровский Завод, Игначевский Иосиф, слесарь - Тарбагатайская волость, Молиенко Иосиф, сапожник - Петровский Завод, Прушинский Иосиф, сапожник - Петровский Завод, Синдер Нохейм, булочник - Петровский Завод и т. д. ${ }^{9}$

Как видим, в Прибайкалье старались остаться «простые» поляки, люди рабочих профессий и бедняки-крестьяне. Шляхтичи из Речи Посполитой, а также помещики из Литвы и Белоруссии стремились скорее покинуть «холодную Сибирь». Следует сказать, что в этом в немалой степени им помогало и царское правительство, проявляя вполне понятную здесь сословную солидарность. Иначе не объяснить поистине беспрецедентных льгот, которые предназначались ссыльным участникам Январского восстания в каждом высочайшем манифесте, принимавшемся в России по случаю всевозможных торжеств, происходивших периодически в монаршем доме. Попробуем доказать фактически этот тезис.

По нашим сведениям, первый подобный манифест был принят уже 28 октября 1866 г. по случаю бракосочетания наследника престола. «Признавая в возможности миловать и прощать, когда милосердием не ослабляется сила закона», манифест объявлял каторжанам-полякам, чье поведение было «безукоризненным», замену «вечного» наказания срочным, другим же сокращал каторгу на четверть или даже треть. Поселенцам по суду манифест разрешал «по пробытии в ссылке не менее пяти лет» приписываться к сельским обществам (для русских «политиков» - этот срок был в два раза больше), а тем, кто был подвергнут до суда телесным наказаниям, сроки на приписку к городам и селам сокращались вообще наполовину, независимо от того, когда «бунтовщик» поступил в ссылку. Далее, сосланным на житье, а это и были в основном люди состоятельные и родовитые, сокращались сроки пребывания на одну треть; а вот «водворенцы», основу которых составляли «простолюдины», могли лишь «просить» о перемещении в другие отдаленные губернии вне Сибири» и только «по пробытии в ссылке не менее пяти лет» ${ }^{10}$. Следует подчеркнуть, что данный манифест был принят в октябре 1866 г., через 3 месяца после подавления восстания ссыльных поляков на Кругобайкальском тракте.

Второй известный нам манифест, принятый 17 мая 1867 г., носил такой же сословный характер. В нем государь повелеть соизволил «все дела политического свойства, касающиеся последнего мятежа и беспорядков, имевших отношение к оному, неоконченные еще производством, как в следственных комиссиях, так и в судебных местах - если лица, прикосновенные к этим делам, не обвиняются кроме того в особых уголовных преступлениях, как то: в убийстве, поджоге и т. п. - прекратить, освободив всех обвиняемых от следствия и суда». Далее документ предусматривал: «новые дела, которые могут возникать по обвинениям в принадлежности к бывшему мятежу или политическим беспорядкам, бывшим в связи с мятежом, не вчинать», а всем административно-высланным, к которым относились и сосланные на житье, вообще дозволить возвратиться на родину, не распространяя, впрочем,

${ }^{9}$ ГАИО. Ф. 24. Оп. Оц. Д. 814. Л. 2 об.

${ }^{10}$ Манифест «О Всемилостивейше дарованных милостях и облегчениях по случаю бракосочетания Его Императорского Высочества Государя Наследника Цесаревича и Великого князя Александра Александровича» // Полное собрание законов Российской Империи. Собр. второе. T. XLI. Отд. второе. 1866. СПб., 1868. № 43784.

\section{Baikal Research Journal}

электронный научный журнал Байкальского государственного университета 
сего общего разрешения на лиц духовного звания». Как видим, о сосланных на водворение - ни слова ${ }^{11}$.

Третий документ, имеющийся в нашем распоряжении, - именной, объявленный Сенату министром юстиции, опубликованный 25 мая 1868 г. манифест «О даровании облегчения осужденным до 1-го января 1866 года политическим преступникам». Как следует из текста, каторга для участников восстания, кого местные власти признают благонадежным, отменялась вообще и заменялась поселением; бывшим на поселении предоставлялись «права государственных поселян» с дозволением им «жительства в городах для занятия ремеслами и промышленностью, но с воспрещением при этом участвовать в выборах и быть избираемыми в общественную службу, а также отлучаться из Сибирского края». Сосланным на житье дозволялось просить местное начальство о переводе их на жительство в те Европейские губернии империи, «кои будут указаны министром внутренних дел по соглашению с шефом жандармов». Наконец, всем находящимся в Сибири иностранцам, а также молодым людям, впавшим в преступление по «Польскому мятежу» и не имея 20 лет от роду, даровалось прощение, с разрешением проживать на родине. И все эти льготы - уже через пять лет после восстания! И опять о «водворенцах» нет даже упоминания ${ }^{12}$.

Получив манифест, председательствующий в Совете ГУВС генерал-лейтенант К. Н. Шелашников конфиденциальным письмом просил Нерчинского коменданта полковника А. Е. Кноблоха «приступить к исполнению изъясненной высочайшей воли», для чего распорядиться высылать каторжников Нерчинских заводов, подлежащих освобождению от работ партиями от 80-100 человек пешим порядком в Читу для дальнейшего их отправления в Иркутск», что и было выполнено. Вместе с тем столь масштабные льготы не коснулись, к примеру, Н. Г. Чернышевского: согласно особому предписанию министра внутренних дел и шефа Корпуса жандармов от 13 февраля 1869 г. он был «изъят» от действия манифеста и оставлен в Александровском заводе [10, с. 25].

13 мая 1871 г. было объявлено очередное «всемилостивейшее повеление», согласно которому всем привилегированным ссыльным, переведенным на основании манифестов 1866 и 1868 гг. из Сибири в Европейскую Россию на жительство под надзор полиции, возвращались прежние права состояния, «но без прав на прежнее имущество тех из них, которые были лишены сего судебными приговорами» ${ }^{13}$.

Как видим, привилегии дворянского класса охранялись законодательно даже для политических ссыльных, лишенных судом "всех особенных прав и преимуществ». Сословная солидарность высших российских чиновников и польских помещиков - участников Январского национального восстания, действовала безотказно и в Сибири, давая последним «преимущества» и принося всевозможные «послабления». Для иллюстрации этого тезиса приведем отрывок из воспоминаний Э. Андреоли - дворянина, французского добровольца Гарибальдийского отряда, участвовавшего в боях с российскими войсками на территории Польши, попавшего в плен и отправленного с товарищами в Нерчинские рудники по этапу. Андреоли описывает процедуру принятия ссыльных в Тобольском приказе: «Нас измеряют ростомером, нас рассматривают и внезапно один из служивших приближается к одному из наших и хочет ему открыть рот; удар кулаком, который он получил, от-

\footnotetext{
${ }^{11}$ Именной, объявленный Сенату министром внутренних дел, распубликованный 26 -го того же мая «О лицах, прикосновенных к делам политического свойства, касающимся последнего Польского мятежа» // Полное собрание законов Российской Империи. Собр. второе. T. XLII. Отд. первое. 1867. Май 17 1867. № 44601. СПб., 1871.

${ }^{12}$ Именной, объявленный Сенату министром юстиции, распубликованный 25 -го того же мая манифест «О даровании облегчения осужденным до 1-го января 1866 года политическим преступникам» // Там же. Т. XLIII. Отд. первое. 1868. Май 25. № 45898. СПб., 1873.

${ }^{13}$ ГАИО. Ф. 32. Оп. 1. Д. 30. Л. 2.
}

\section{Baikal Research Journal}


брасывает его на три шага к столу; кажется, он хотел выполнить с нами все предписанные формальности, но ему сосчитали зубы. Бедный малый был сговорчив; он понял, что ошибся, схватив за лицо привилегированного, и попросил прощения» [11, с. 157-158].

Итак, «всемилостивейшие манифесты», существенно облегчавшие судьбу ссыльных участников Январского восстания в Сибири (по подсчетам В. Сливовской, всего за 1866-1883 гг. было опубликовано «девять манифестов и указов» [12, с. 24]), принимались по сословному принципу и практически не касались «простых" поляков, отбывавших наказание водворением. Для этой категории ссыльных первые серьезные «послабления» были приняты лишь к середине 1870-х г. Так, в 1874 г. сосланным на водворение в административном порядке было разрешено вернуться на родину, но при условии одобрительного поведения в месте ссылки и только после согласия начальника края, откуда высланный был родом, причем, вернуться могли те, кто имел собственные средства на дорогу [13, с. 29].

Возвращение ссыльных поляков растянулось на значительный срок. Даже если ходатайства об отъезде отдельных семей водворенцев удовлетворялись, такие ссыльные должны были вернуть все пособия и ссуды, полученные в Сибири, что значительно отдаляло возвращение или делало его вообще невозможным. Наконец в 1883 г. всем ссыльным полякам было предоставлено право отъезда на родину, однако, как считает В. Сливовская, «еще более десятилетия поляки, участники восстания 1863 г., отбывали наказание в разных частях империи. Лишь манифест Николая II от 14 ноября 1894 г. и следующий - от 14 мая 1896 г. позволил остаткам сосланных повстанцев вернуться на родину» [12, с. 26].

Подведем некоторые итоги. Правовые условия пребывания поляков - участников Январского восстания - в Иркутской ссылке в 1863-1883 гг. имели свои особенности. Перечень запрещаемых занятий для ссыльных поляков был гораздо шире обычного, действовавшего для русских революционеров, а контроль за из перемещением - строже. Пребывание в ссылке участников Январского восстания регулировалось особыми правилами, а также несколькими законодательными актами, направленными на обеспечение более эффективной деятельности по организации надзора и размещению контингента ссыльных. Прибытие на территорию губернии значительного контингента ссыльных вызвало создание Нерчинского комендантского управления, повлекло за собой структурные изменения в высших административных органах губернии.

Анализ имеющихся исторических источников свидетельствует, что ссылка польских «мятежников» имела сложную организационную структуру. Среди ссыльных были каторжане, приговоренные судом к наказанию без срока и на срок от пяти лет и выше; сосланные на поселение по суду и вышедшие на оное после отбытия каторжных работ; высланные на жительство и водворение. Поляки-каторжане отбывали наказание на солеваренных и горнодобывающих предприятиях Иркутской губернии и Забайкальской области, а поселенцы размещались среди старожильческого крестьянского населения. Немалая часть поляков, окончив формальные сроки ссылки, приписывалась к сельским обществам и осталась в Сибири навсегда.

Наказанию каторжными работами и ссылкой на поселение подвергались наиболее деятельные участники восстания, его организаторы и активные исполнители. Среди высланных на жительство в пределы Иркутской губернии преобладали люди состоятельные и родовитые. Ссылка на водворение, наоборот, касалась в основном поляков «простого» звания. Политическая ссылка вообще, и поляков в том числе, не отменяла классовых и сословных привилегий, «знатный» и материально обеспеченный ссыльный переносил тяготы невольного нахождения в Сибири гораздо легче ссыльных из мещанского или крестьянского сословия.

\section{Baikal Research Journal}

электронный научный журнал Байкальского государственного университета 
Анализ источников законодательного характера свидетельствует о стремлении высшего российского чиновничества всячески облегчить условия пребывания в ссылке польских и литовских дворян. Именно по этой причине уже с 1866 г. принимаются меры по существенному сокращению сроков их ссылки, а затем и частичной амнистии.

\section{Список использованной литературы}

1. Шостакович Б. С. Феномен польско-сибирской истории (XVII в. - 1917 г.). Основные аспекты современных научных трактовок, результатов и задач дальнейшей разработки темы / Б. С. Шостакович. - М. : МИК, 2015. - 752 с.

2. Иванов А. А. Историография политической ссылки в Сибирь второй половины XIX начала ХХ в. / А. А. Иванов. - Иркутск : Изд-во Иркут. гос. ун-та, 2001. - 275 с.

3. Рощевская Л. П. История политических репрессий в царской России : учеб. пособие / Л. П. Рощевская. - Сыктывкар : Изд-во Сыктывк. гос. ун-та, 2006. - 140 с.

4. Стшижевская С. Ссыльные участники Январского восстания / С. Стшижевская // Сибирь в истории и культуре польского народа. - М. : Ладомир, 2002. - С. 124-134.

5. Колмаков Ю. П. Иркутская летопись. 1661-1940 / Ю. П. Колмаков. - Иркутск : Оттиск, 2002. - $848 \mathrm{c.}$

6. Пантелеев Л. Ф. Воспоминания / Л. Ф. Пантелеев. - М. : Гослитиздат, 1958. - 848 с.

7. Иркутская лътопись. 1857-1880 г. : (Продолжение «Лътописи» П. И. Пежемскаго и В. А. Кротова) / сост. Н. С. Романовъ ; под ред. И. И. Серебренникова. - Иркутск : Паровая тип. И. П. Казанцева, 1914. - 427с. - (Труды Вост.-Сиб. Отдъла Императорскаго Русскаго Географическаго Общества ; № 8).

8. Клер Л. С. Второе комендантское управление на Нерчинских заводах (1846-1874) / Л. С. Клер, Б. С. Шостакович // Ссыльные революционеры в Сибири (XIX в. - февраль 1917 г.). - Иркутск : Изд-во Иркут. ун-та, 1987. - Вып. 10. - С. 101-122.

9. Дворянов В. Н. В Сибирской дальней стороне ... (очерки истории царской каторги и ссылки. 60-е годы XVIII в. - 1917 г.) / В. Н. Дворянов. - Минск : Наука, 1971. - 374 с.

10. Багаутдинов А. З. Н. Г. Чернышевский на каторге (Усолье - Кадая, 1864-1866 гг.) / А. З. Багаутдинов // Записки Иркутского областного краеведческого музея : сб. ст. и материалов / под ред. Ф. А. Кудрявцева. - Иркутск : Вост.-Сиб. кн. изд-во, 1965. - С. 25-27.

11. Андреоли Э. Из Польши в Сибирь (дневник военнопленного 1863-1867) : пер. с фр. / Э. Андреоли. - Чита : Экспресс-издательство, 2011. - 332 с.

12. Сливовская В. Побеги из Сибири : пер. с пол. / В. Сливовская. - СПб. : Алетейя, 2014. $-536 \mathrm{c}$.

13. Мулина С. А. Мигранты поневоле: адаптация ссыльных участников Польского восстания 1863 года в Западной Сибири / С. А. Мулина. - СПб. : Алетейя, 2012. — 200 с.

\section{References}

1. Shostakovich B. S. Fenomen pol'sko-sibirskoi istorii (XVII v. - 1917 g.). Osnovnye aspekty sovremennykh nauchnykh traktovok, rezul'tatov i zadach dal'neishei razrabotki temy [The phenomenon the Pole-Siberian of history (XVIIth century-1917) Main aspects of present-day scientific interpretations, results and further development of the topic]. Moscow, МИК Publ., 2015. 752 p.

2. Ivanov A. A. Istoriografiya politicheskoi ssylki $v$ Sibir' vtoroi poloviny XIX - nachala $X X v$. [Historiography of political exile to Siberia in the second half of XIX-early XX centuries, Irkutsk State University Publ., 2001. 275 p.

3. Roshchevskaya L. P. Istoriya politicheskikh repressii $v$ tsarskoi Rossii [History of political repressions in the Tsar Russia]. Syktyvkar State University Publ., 2006. 140 p.

4. Stshizhevskaya S. The exiled participants of January revolt. Sibir' v istorii i kul'ture pol'sk ogo naroda [Siberia in history and culture of the Polish people]. Moscow, Ladomir Publ., 2002, pp. 124-134. (In Russian).

5. Kolmakov Yu. P. Irkutskaya letopis'. 1661-1940. [The Irkutsk Annals. 1661-1940]. Irkutsk, Ottisk Publ., 2002. 848 p.

6. Panteleyev L. F. Vospominaniya [Memoirs]. Moscow, Goslitizdat Publ., 1958. 848 p.

7. Romanov N. S., Serebrennikov (eds). Irkutskaya l"topis'. 1857-1880 g. (Prodolzhenie "L"topisi» P. I. Pezhemskago i V. A. Krotova) [The Irkutsk Annals. 1857-1880 (Continuation of "Annals» of P. I. Pezhemsky and V.A. Krotov)]. Irkutsk, I. P. Kazantsev Publ., 1914. 427 p.

\section{Baikal Research Journal}


8. Kler L. S., Shostakovich B. S. The second commandant administration at the Nerchinnsk Works (1846-1874). Ssyl'nye revolyutsionery v Sibiri (XIX v. - fevral' 1917 g.) [Exiled revolutionists in Siberia (19th century - February 1917)]. Irkutsk State University Publ., 1987, iss. 10, pp. 101-122. (In Russian).

9. Dvoryanov N. V. V sibirskoi dal'nei storone. Ocherki istorii tsarskoi katorgi i ssylki. 60-e gody XVIII v. $-1917 \mathrm{~g}$. [On the far side of Siberia. Short notes on penal servitude and exile in 1760-1917]. Minsk, Nauka Publ., 1971. 374 p.

10. Bagautdinov A. Z. N. G. Chernyshevsky in the exile (Usolye-Kadaya, 1864-1866). In Kudryavtsev F. A. (ed.). Zapiski Irkutskogo oblastnogo kraevedcheskogo muzeya [Proceedings of Irkutsk Oblast Museum of Regional Studies. Irkutsk, Vostochno-Sibirskoe knizhnoe izdatel'stvo Publ., 1965, pp. 25-27. (In Russian).

11. Andreoli E. Iz Pol'shi v Sibir' (dnevnik voennoplennogo 1863-1867) [From Poland to Siberia (a diary of a prisoner-of-war of 1863-1867))]. Chita, Ekspress-izdatel'stvo Publ., 2011. $332 \mathrm{p}$.

12. Slivovskaya V. Pobegi iz Sibiri [Runaways from Siberia]. Saint Petersburg, Aleteiya Publ., 2014. 536 p.

13. Mulina S. A. Migranty ponevole: adaptatsiya ssyl'nykh uchastnikov Pol'skogo vosstaniya 1863 goda $v$ Zapadnoi Sibiri [Migrants willy-nilly: adaption od exiled participants of Polish revolt of 1863 in Western Siberia]. Saint Petersburg, Aleteiya Publ., 2012. 200 p.

\section{Информация об авторе}

Иванов Александр Александрович - доктор исторических наук, профессор, кафедра политологии, истории и регионоведения, Иркутский государственный университет, 664003, г. Иркутск, ул. К. Маркса, 1, e-mail: ottisk@irmail.ru.

\section{Author}

Alexander A. Ivanov - Doctor habil. (History), Professor, Chair of Political Sciences, History and Regional Studies, Irkutsk State University, 1 K. Marx St., 664003, Irkutsk, Russian Federation; e-mail: ottisk@irmail.ru.

\section{Библиографическое описание статьи}

Иванов А. А. Правовые особенности пребывания поляков - участников Январского восстания - в Иркутской ссылке в 1863-1883 гг. / А. А. Иванов // Baikal Research Journal. 2016. 一 T. 7, № 5. — DOI : 10.17150/2411-6262.2016.7(5).13.

\section{Reference to article}

Ivanov A. A. Legal features of Poles' sojourn - participants of January revolt - in Irkutsk exile in 1863-1883. Baikal Research Journal, 2016, vol. 7, no. 5. DOI : 10.17150/24116262.2016.7(5).13. (In Russian).

\section{Baikal Research Journal}

